Article

\title{
The Endogenous Opioid System in Schizophrenia and Treatment Resistant Schizophrenia: Increased Plasma Endomorphin 2, and $\kappa$ and $\mu$ Opioid Receptors Are Associated with Interleukin-6
}

\author{
Shatha Rouf Moustafa ${ }^{1}$ (D), Khalid F. Al-Rawi ${ }^{2}$, Drozdstoi Stoyanov ${ }^{3}$ (D, \\ Arafat Hussein Al-Dujaili ${ }^{4}$, Thitiporn Supasitthumrong ${ }^{5}$ (D) Hussein Kadhem Al-Hakeim ${ }^{6}$ (D) \\ and Michael Maes $3,5,7, *$ \\ 1 Clinical Analysis Department, College of Pharmacy, Hawler Medical University, Havalan City, Erbil 44001, \\ Iraq; shatha003@yahoo.com \\ 2 College of Science, University of Anbar, Ramadi 31001, Iraq; sc.kfwi72@uoanbar.edu.iq \\ 3 Department of Psychiatry, Medical University of Plovdiv, Plovdiv 4000, Bulgaria; \\ stojanovpisevski@gmail.com \\ 4 Clinical Psychiatry, Faculty of Medicine, University of Kufa, Najaf 540011, Iraq; \\ arafat.aldujaili@uokufa.edu.iq \\ 5 Department of Psychiatry, Faculty of Medicine, Chulalongkorn University, Bangkok 10110, Thailand; \\ Thitiporn.S@chula.ac.th \\ 6 Department of Chemistry, College of Science, University of Kufa, Najaf 540011, Iraq; headm2010@yahoo.com \\ 7 School of Medicine, IMPACT Strategic Research Centre, Deakin University, Geelong, VIC 3220, Australia \\ * Correspondence: dr.michaelmaes@hotmail.com
}

Received: 8 June 2020; Accepted: 24 August 2020; Published: 26 August 2020

\begin{abstract}
Background: activation of the immune-inflammatory response system (IRS) and the compensatory immune-regulatory system (CIRS) plays a key role in schizophrenia (SCZ) and treatment resistant SCZ. There are only a few data on immune and endogenous opioid system (EOS) interactions in SCZ and treatment resistant SCZ. Methods: we examined serum $\beta$-endorphin, endomorphin-2 (EM2), mu-opioid (MOR) and kappa-opioid (KOR) receptors, and interleukin (IL)-6 and IL-10 in 60 non responders to treatment (NRTT), 55 partial RTT (PRTT) and 43 normal controls. Results: serum EM2, KOR, MOR, IL-6 and IL-10 were significantly increased in SCZ as compared with controls. $\beta$-endorphin, EM2, MOR and IL-6 were significantly higher in NRTT than in PRTT. There were significant correlations between IL-6, on the one hand, and $\beta$-endorphin, EM2, KOR, and MOR, on the other, while IL-10 was significantly correlated with MOR only. A large part of the variance in negative symptoms, psychosis, hostility, excitation, mannerism, psychomotor retardation and formal thought disorders was explained by the combined effects of EM2 and MOR with or without IL-6 while increased KOR was significantly associated with all symptom dimensions. Increased MOR, KOR, EM2 and IL-6 were also associated with neurocognitive impairments including in episodic, semantic and working memory and executive functions. Conclusion: the EOS contributes to SCZ symptomatology, neurocognitive impairments and a non-response to treatment. In SCZ, EOS peptides/receptors may exert CIRS functions, whereas increased KOR levels may contribute to the pathophysiology of SCZ and EM2 and KOR to a non-response to treatment.
\end{abstract}

Keywords: inflammation; schizophrenia; treatment resistance; neurocognition; neuroimmunomodulation 


\section{Introduction}

The first comprehensive neuro-immune theory of schizophrenia (SCZ) was published by Smith and Maes in 1995 and suggested that activated monocytes and T-lymphocytes are key phenomena in the pathophysiology of SCZ [1]. Now, it is widely accepted that SCZ is accompanied by activation of the immune-inflammatory response system (IRS) with activated M1 macrophages as indicated by increased levels of interleukin (IL)-6, IL-1 $\beta$ and tumour necrosis factor-alpha (TNF $\alpha$ ) levels, T-helper (Th)- 1 cells and Th-17 cells [2-8]. SCZ is also accompanied by activation of the compensatory immune-regulatory system (CIRS) with increased activity of Th-2 immunocytes as indicated by increased levels of IL-4 and IL-13, and T-regulatory (Treg) cells with increased production of IL-10, and elevated levels of immune-regulatory compounds including acute phase proteins (e.g., haptoglobin) and soluble interleukin receptors such as sIL-2R, sIL-1RA, sTNFR1 and sTNFR2 [7,8]. Importantly, IRS and CIRS products including IL-1 $\beta$, TNF- $\alpha$, IL-6, IFN- $\gamma$, IL-4, IL-13, eotaxin (CCL11) and neurotoxic tryptophan catabolites (TRYCATs) may all cause neuroprogression and, as a consequence, deficits in memory and executive functions and, therefore, SCZ symptoms [4,6,9-14].

Treatment-resistant schizophrenia (TRS) is also accompanied by signs of IRS and CIRS including M1 (especially IL-6 trans-signaling and TNF $\alpha$ ) and Treg (IL-10) cell activation as well as increased levels of soluble IL-2 receptor (sIL-2R), the sIL-1R antagonist (sIL-1RA), and sTNFR2 [2,4,8,15].

Endogenous opioids (EOs) are expressed in the peripheral and central nervous system where they modulate pain, reward, aversion, reinforcement, social bonding, and neurotransmitter signalling including that of glutamate and dopamine $[16,17]$. During IRS activation, immunocytes produce and release EOs [18] and express $\mu$ (MOR) and $\kappa$ (KOR) opioid receptors [19]. In humans and animal models, EOs negatively regulate immune responses $[20,21]$ including downregulation of cytokine and chemokine levels and associated receptors [22] and immune cell proliferation and activities [23].

Aberrations in EO system (EOS) activity are observed in SCZ, including changes in the levels of endorphins, and MOR and KOR expression [24,25]. In the post-mortem brain of SCZ patients, lowered MOR expression is observed in the striatum [25]. Because MORs mediate hedonic and social reward processing, lowered MOR expression may explain social impairments and other negative symptoms of SCZ [26]. $\beta$-Endorphin concentrations are increased in SCZ patients with negative symptoms and decreased in patients with positive symptoms as compared with controls [27]. Interestingly, clinical reports indicate that some SCZ patients are less sensitive to pain [28], suggesting increased EOS activity. Endomorphin-2, another EOS peptide, has high selectivity and affinity for MOR and mediates stress responses, sensitivity to pain, arousal, vigilance, reward, neuroendocrine and neurocognitive functions [29], suggesting that this peptide may play a role in SCZ.

In major depression, significant associations were established between increased plasma KOR/MOR levels, on the one hand, and elevated plasma IL- 6 and IL-10, on the other, indicating that immune-EOS interactions play a role in the pathophysiology of depression [30]. Furthermore, IL-6 regulates the KOR gene [31] and MOR expression [32], while IL-10 increases $\beta$-endorphin gene and protein expression [33]. Since KOR/MOR/ $\beta$-endorphin have immune-regulatory effects and since these products are upregulated in major depression, it was hypothesized that their increased levels might contribute to CIRS functions in depression [30]. However, in SCZ and TRS, no data are available on endomorphin 2 and possible associations between EOS compounds and IRS/CIRS functions.

Hence, this study was performed to examine serum levels of $\beta$-endorphin and endomorphin 2 as well as MOR and KOR in association with IL-6 and IL-10 in SCZ and TRS.

\section{Participants and Methods}

\subsection{Participants}

In the current study, two groups of SCZ patients participated, namely 60 non responders to treatment (NRTT) and 55 partial responders to treatment (PRTT) and 43 healthy volunteers. The participants were of both sexes and aged 18-65 years. NRTT and PRTT were recruited at the 
Psychiatry Unit at Al-Imam Al-Hussain Medical City in Karbala, Iraq. All patients were diagnosed using the criteria of the diagnostic and statistical manual of mental disorders, fourth edition, text revision (DSM-IV-TR). NRTT was defined as non-responders to two episodes of treatment (each for at least two months), with two different antipsychotic drugs at adequate doses, without a decrease in symptom severity as screened using the Clinical Global Impression Severity (CGI-S) scale [34]. Healthy volunteers were family members or friends of staff. Patients and controls were recruited from the same catchment area, namely Karbala city, Iraq. SCZ patients who showed axis-1 DSM-IV-TR diagnoses other than SCZ were excluded from the study, including autism spectrum disorders, major depression, psycho-organic disorders, bipolar disorder, and schizoaffective disorder. Healthy controls were excluded if they had a current or lifetime diagnosis of axis I diagnosis or had a positive family history of SCZ. Moreover, patients and controls were excluded when they (a) suffered from medical disorders including chronic obstructive pulmonary disease, diabetes, rheumatoid arthritis, inflammatory bowel disease and psoriasis; and (b) suffered from neuroinflammatory or neurodegenerative disorders including Parkinson's disease, stroke, Alzheimer's disease and multiple sclerosis. Any subjects who had ever been taken immune-modulatory medications such as glucocorticoids were excluded from participating. We also excluded subjects who took therapeutic doses of antioxidant supplements 3 months before the blood aspiration. All participants showed serum C-reactive protein (CRP) levels $<6 \mathrm{mg} / \mathrm{L}$ indicating the absence of overt inflammation.

All patients and controls, along with the guardians of patients (parents or the first-degree family members), provided written informed consent prior to participation in the study. The study was carried out according to international and Iraq ethics and privacy laws. The study was approved by the Institutional Review Board of the University of Karbala (418/12 July 2019), and Karbala Health Department (1331/26, July, 2019), which is in agreement with the International Guidelines for Human Research protection as requested by the Declaration of Helsinki, The Belmont Report, Council for International Organizations of Medical Sciences guideline and International Conference on Harmonization in Good Clinical Practice.

\subsection{Measurements}

\subsubsection{Clinical Evaluations}

A senior psychiatrist specialized in SCZ diagnosed the patients according to DSM-IV-TR criteria using the Mini-International Neuropsychiatric Interview (MINI), in a validated Arabic translation (Iraqi dialect). The same psychiatrist employed a semi-structured interview to assess socio-demographic and clinical data in all participants and the same day he also assessed the Clinical Global Impression (CGI) Improvement (CGI-I) and Severity (CGI-S) Scales [34]. The CGI-I was used to identify NRTT when they did not show any improvement on the CGI-I or showed poorer scores after treatment (minimally worse, much worse, very much worse). The diagnosis "responders to treatment" was made in case the CGI-I scores improved minimally, much or very much. However, since no patients showed remission after treatment, this group was named PRTT. Furthermore, we assessed the Scale for the Assessments of Negative Symptoms (SANS) to measure the severity of negative symptoms [35]. We also computed $\mathrm{z}$ unit-weighted composite scores to reflect the severity of psychosis, hostility, excitation, mannerism, FTD (formal thought disorders) and PMR (psychomotor retardation) [10,12,14]. Toward this end, we assessed the Brief Psychiatric Rating Scale (BPRS) [36], the Hamilton Depression Rating Scale [37] and the Positive and Negative Syndrome Scale (PANNS) [38]. The same psychiatrist also completed the Brief Assessment of Cognition in SCZ (BACS) [39] to assess episodic memory (using the List learning test); working memory (using the Digit Sequencing Task); verbal fluency (using the Controlled Word Association and Category instances tests); attention (using the symbol coding test); and executive functions (using the Tower of London). Tobacco use disorder (TUD) was examined according to DSM-IV-TR criteria. Body mass index (BMI) was calculated from the formula: body weight $(\mathrm{kg})$ /squared length $\left(\mathrm{m}^{2}\right)$. 


\subsubsection{Assays}

Five milliliters of venous blood samples were collected after an overnight fast between 8.00 and 9.00 a.m. After clotting, blood was centrifuged at $3000 \mathrm{rpm}$ for $10 \mathrm{~min}$, and serum was separated and transferred into two Eppendorf tubes which were stored at $-80{ }^{\circ} \mathrm{C}$ until analysis. Serum levels of IL-10 (Elabscience ${ }^{\circledR}$, Inc., San Carlos, CA, USA), MOR, KOR, and endomorphin 2 (Mybiosource ${ }^{\circledR}$, Inc., San Diego, CA, USA), and IL-6 and $\beta$-endorphin (Melsin Medical Co, Jilin, China) were assayed used commercial ELISA kits. All measured concentrations of $\beta$-endorphins (sensitivity $=0.1 \mathrm{pg} / \mathrm{mL}$ ), MOR (sensitivity $=7.18 \mathrm{pg} / \mathrm{mL}$ ), KOR (sensitivity $=1.0 \mathrm{ng} / \mathrm{mL}$ ), endomorphin 2 (sensitivity $=0.33 \mathrm{pg} / \mathrm{mL}$ ), and IL-6 (sensitivity $=0.1 \mathrm{pg} / \mathrm{mL}$ ) were greater than their assay sensitivities. There was only one IL-10 measurement (namely $4.05 \mathrm{pg} / \mathrm{mL}$ in a normal volunteer) that was lower than the sensitivity of the assay (sensitivity $=4.69 \mathrm{pg} / \mathrm{mL}$ ). Therefore, we did not apply left-censoring of the data and employed the measured IL-10 concentration in our statistical analyses [4]. All intra-assay coefficients of variation were $<10.0 \%$. Serum CRP was measured using a kit supplied by Spinreact ${ }^{\circledR}$, Girona, Spain, using a test based on the latex agglutination principle.

\subsection{Statistical Analysis}

We used analysis of variance or the Kruskal-Wallis test to check the differences in scale variables between categories and the Chi square test $\left(\chi^{2}\right.$-test) or the $\psi$ nominal by nominal coefficient (in cases of more than $20 \%$ of the cells having expected cell counts $<5$ ) to assess the associations between categorical variables. Associations among biomarkers, cognitive and clinical scores were computed employing Pearson's product-moment and Spearman's rank-order correlation coefficients. Associations between diagnosis and biomarkers were examined using multivariate general linear model (GLM) analysis while controlling for confounding variables including age, sex, TUD, BMI, and education. Consequently, we performed tests for between-subject effects to delineate the associations between diagnosis and each of the biomarkers. The effect size was assessed using partial eta-squared values $\left(\eta^{2}\right)$. We also computed the model-generated estimated marginal mean (SE) values and used protected pairwise comparisons among treatment means to assess differences between the diagnostic groups. Binary logistic regression analysis was employed to delineate the best predictors of SCZ versus controls and NRTT versus PRTT using the serum biomarkers levels as explanatory variables. Nagelkerke values, which were used as pseudo- $R^{2}$ values, were computed along with Odd's ratios with $95 \%$ confidence intervals. We used multiple regression analysis to assess the significant biomarkers, which predict the neurocognitive test results and symptom dimensions while permitting for probable effects of education, age, and sex. We used an automatic stepwise method with the inclusion of variables with a p-to-entry of 0.05 and p-to-remove of 0.06 while checking the $R^{2}$ change. All regression analyses were checked for collinearity using tolerance and variance inflation factor values. One of the assumptions of multiple regression analysis is that the error term (between predicted and observed) is normally distributed and, therefore, we checked normality of distribution of the regression standardized residuals. Furthermore, heteroscedasticity was checked by scatterplots of residual values versus the predicted values. Tests were 2-tailed and a p-value of 0.05 was used for statistical significance. All statistical analyses were performed using IBM SPSS windows version 25, 2017. The study sample was based on power calculations using G*Power version 3.1.9.7, Heinrich-Heine-Universität Düsseldorf, Germany (downloaded freely from https://www.psychologie.hhu.de/arbeitsgruppen/allgemeine-psychologieund-arbeitspsychologie/gpower.html). Using an effect size of 0.23 , alpha $=0.05$, power $=0.8$ in an analysis of covariance with three groups and four covariates showed that the study sample should be $n=151$. Using the same input parameters in a multiple regression model (with $\mathrm{R}^{2}$ deviation from zero) showed that a study sample of $n=65$ would be sufficient. 


\section{Results}

\subsection{Socio-Demographic Data}

Table 1 shows the socio-demographic data of the PRTT and NRTT and healthy controls. We included 142 SCZ patients who were treated with antipsychotic drugs during two trials with antipsychotic medications. During the first trial, patients were treated for 2 months and after this trial divided into those with a partial response $(n=51)$ and those without a clinical response $(n=84)$ (we lost seven patients through this first trial). The partial responders continued to take the similar medication for another two months while we missed again seven patients in the follow up producing a final PRTT study group of $n=55$. The non-responders to the initial antipsychotic drug were switched to another antipsychotic drug for another 2 months and during this follow-up period we missed again thirteen patients. Two months later, eleven patients had a partial response to treatment and were categorized as PRTT, whereas sixty patients did not show any improvement on the CGI-I and, therefore, were categorized as NRTT. Consequently, fifty-five PRTT and sixty NRTT participated in the current study.

There were no significant differences in age, BMI, sex ratio, and TUD between NRTT and PRTT and normal controls. There were slightly more NRTT patients who were single as compared with the normal control group. SCZ patients were significantly more unemployed as compared with controls while years of education were slightly lower in NRTT. There were no differences in age at onset between both patients' subgroups. All cognitive test scores (except symbol coding) were significantly different among the three study groups and the scores decreased from controls to PRTT to NRTT. We did not correct the cognitive results for type one errors due to multiple comparisons because these test results are reflective manifestations of a single underlying trait, namely a disorder in the cognitome [40]. The total SANS score was significantly different between the three study groups.

In Table 1, both the CGI-I and CGI-S scores were significantly higher in NRTT than in PRTT. The CGI-I scores in PRTT were two (much improved)-three (minimally improved) and in NRTT four (no change)-five (minimally worse). Patients in the NRTT group were more often treated with clozapine, risperidone, and quetiapine than PRTT who were more often treated with haloperidol and olanzapine.

The following symptom domains were significantly different between the three study groups and increased from controls to PRTT to NRTT: excitement $(\mathrm{F}=320.71, \mathrm{df}=2 / 152, p<0.001), \mathrm{FTD}(\mathrm{F}=414.15$, $\mathrm{df}=2 / 152, p<0.001)$, hostility $(\mathrm{F}=498.12, \mathrm{df}=2 / 152, p<0.001)$, mannerism $(\mathrm{F}=204.41, \mathrm{df}=2 / 152$, $p<0.001), \operatorname{PMR}(\mathrm{F}=297.46, \mathrm{df}=2 / 152, p<0.001)$ and psychosis $(\mathrm{F}=772.55, \mathrm{df}=2 / 152, p<0.001)$. We did not correct these data for type one errors due to multiple testing because the symptom domains are reflective manifestations of a single underlying trait, namely overall severity of schizophrenia [40]. Figure 1 shows a bar graph with the composite scores (in z scores) of these symptom domains as well as the $\mathrm{z}$ values of the total SANS scores.

\subsection{Differences in Biomarkers between the Study Groups}

Table 3 displays the outcomes of a multivariate GLM analysis comparing the differences in the biomarkers between the three study groups while adjusting for age, BMI, and sex. There were significant differences in biomarkers between the study groups with an effect size of 0.213 , while the covariates had no significant effects. Tests for between-subject effects and Table 4 , which shows the estimated marginal mean (SE) values, indicate that all six biomarkers (except $\beta$-endorphin) were significantly higher in SCZ patients as compared with controls. Furthermore, $\beta$-endorphin, MOR, KOR and IL-6 were significantly higher in NRTT than in PRTT and controls. Endomorphin 2 was significantly different between the three groups and increased from controls to PRTT to NRTT. IL-10 was higher in NRTT than in controls while PRTT patients occupied an intermediate position. We also performed a multivariate GLM analysis examining the associations between the six biomarkers measured here and the diagnosis of SCZ versus normal controls while controlling for age, sex and BMI. This analysis 
showed that endomorphin 2, KOR, MOR, IL-6 and IL-10, but not $\beta$-endorphin $(p=0.865)$ were significantly higher is SCZ than in controls (with or without p correction for false discovery rate).

Table 1. Demographic and clinical data of healthy controls (HC) and partial (PRTT) and non (NRTT) responders to treatment.

\begin{tabular}{|c|c|c|c|c|c|c|}
\hline Variables & $\mathrm{HC}^{\mathrm{A}}(n=43)$ & PRTT $^{\text {B }}(n=55)$ & $\operatorname{NRTT}^{C}(n=60)$ & $\mathrm{F} / \varphi / \chi^{2}$ & df & $p$ \\
\hline Age (years) & $33.2(11.1)$ & $36.5(9.5)$ & $36.2(12.3)$ & $F=1.29$ & $2 / 155$ & 0.280 \\
\hline Sex (Female/Male) & $19 / 24$ & $15 / 40$ & $22 / 38$ & $x^{2}=3.08$ & 2 & 0.214 \\
\hline Married (No/Yes) & $12 / 31^{C}$ & $35 / 30$ & $32 / 28^{A}$ & $x^{2}=6.69$ & 2 & 0.035 \\
\hline BMI $\left(\mathrm{kg} / \mathrm{m}^{2}\right)$ & $27.9(4.1)$ & $29.6(4.3)$ & $28.4(4.9)$ & $F=1.90$ & $2 / 155$ & 0.153 \\
\hline TUD (No/Yes) & $30 / 13$ & $44 / 11$ & $40 / 20$ & $x^{2}=2.71$ & 2 & 0.258 \\
\hline Employment (No/Yes) & $17 / 26^{\mathrm{B}, \mathrm{C}}$ & $36 / 19^{\mathrm{A}}$ & $43 / 17^{\mathrm{A}}$ & $x^{2}=11.63$ & 2 & 0.003 \\
\hline Education (years) & $11.1(3.6)^{C}$ & $10.8(4.5)^{C}$ & $8.9(4.7)^{\mathrm{A}, \mathrm{B}}$ & $\mathrm{F}=4.21$ & $2 / 155$ & 0.017 \\
\hline Age at onset (years) & & $27.5(7.5)$ & $29.3(10.2)$ & $\mathrm{F}=1.14$ & $1 / 113$ & 0.287 \\
\hline List learning * & $0.797(0.596)$ & $0.437(0.580)$ & $-0.959(0.688)$ & KW & & $<0.001$ \\
\hline Digit sequencing task $*$ & $1.369(0.530)$ & $-0.221(0.604)$ & $-0.755(0.322)$ & KW & & $<0.001$ \\
\hline Category instances * & $0.821(0.398)$ & $0.136(0.641)$ & $-0.693(1.064)$ & KW & & $<0.001$ \\
\hline COWA* & $1.386(0.373)$ & $-0.149(0.515)$ & $-0.833(0.399)$ & KW & & $<0.001$ \\
\hline Symbol coding & $1.559(0.403)^{B, C}$ & $-0.518(0.216)^{\mathrm{A}}$ & $-0.617(0.267)^{\mathrm{A}}$ & KW & & $<0.001$ \\
\hline Tower of London * & $1.195(0.463)$ & $0.131(0.709)$ & $-0.848(0.486)$ & KW & & $<0.001$ \\
\hline SANS total score * & $11.2(5.0)$ & $52.6(12.2)$ & $91.9(17.0)$ & $\mathrm{KW}$ & & $<0.001$ \\
\hline CGI-I & & $2.73(0.45)$ & $4.20(0.40)$ & $F=342.92$ & $1 / 113$ & $<0.001$ \\
\hline CGI-S & & $4.38(0.49)$ & $5.95(0.70)$ & $F=190.63$ & $1 / 113$ & $<0.001$ \\
\hline Clozapine (No/Yes) & & $55 / 0$ & $46 / 14$ & $\varphi=0.356$ & & $<0.001$ \\
\hline Quietiapin (No/Yes) & & $55 / 0$ & $54 / 6$ & $\varphi=0.225$ & & 0.016 \\
\hline Haloperidol (No/Yes) & & $43 / 12$ & $60 / 0$ & $\varphi=0.357$ & & $<0.001$ \\
\hline Olanzapine (No/Yes) & & $2 / 53$ & $25 / 35$ & $\varphi=0.448$ & & $<0.001$ \\
\hline Risperidone & & $53 / 2$ & $48 / 12$ & $\varphi=0.250$ & & 0.007 \\
\hline
\end{tabular}

Results are shown as mean (SD), except the neuropsychological test scores which are shown as mean (SD) values after considering the effects of age, sex and years of education. All results of general linear model (GLM) analysis (F), analysis of contingency tables $\left(\chi^{2}\right)$, nominal $x$ nominal coefficient $\varphi$, or the Kruskal-Wallis (KW) test. A,B,C: results of pairwise comparisons of ratios or mean values between the diagnostic groups; the letters indicate which columns are significantly different, for example ${ }^{c}$ indicates different from group $c$ that is non responders to treatment (NRTT). * These test scores are significantly different between the three study groups. BMI: Body mass Index; COWA: Controlled Oral Word Association Test; CGI-I: Clinical Global Impression-Improvement scale; CGI-S: Clinical Global Impression- Severity scale; SANS: Scale for the Assessment of Negative Symptoms; TUD: Tobacco use disorder.

Table 2 shows the correlations between the different biomarkers in this study (all tested at $n=158$ ).

Table 2. Correlation matrix between the biomarkers included in this study.

\begin{tabular}{ccccccc}
\hline Variables & IL-6 & IL-10 & $\beta$-Endorphin & Endomorphin 2 & KOR & MOR \\
\hline IL-6 & & & & \\
\hline IL-10 & 0.152 & & & \\
\hline$\beta$-endorphin & $0.173^{*}$ & 0.090 & & \\
\hline Endomorphin 2 & $0.253^{* *}$ & 0.005 & $0.254^{* *}$ & & \\
\hline KOR & $0.491^{* *}$ & 0.084 & 0.113 & $0.385^{* *}$ & \\
\hline MOR & $0.333^{* *}$ & $0.289^{* *}$ & 0.090 & 0.015 & $0.449^{* *}$ \\
\hline$* p<0.05^{* *} p \leq 0.001$, IL: interleukin; KOR: K-opioid receptor; MOR: H-opioid receptor.
\end{tabular}

${ }^{*} p<0.05,{ }^{* *} p \leq 0.001, \mathrm{IL}$ : interleukin; KOR: k-opioid receptor; MOR: $\mu$-opioid receptor. 


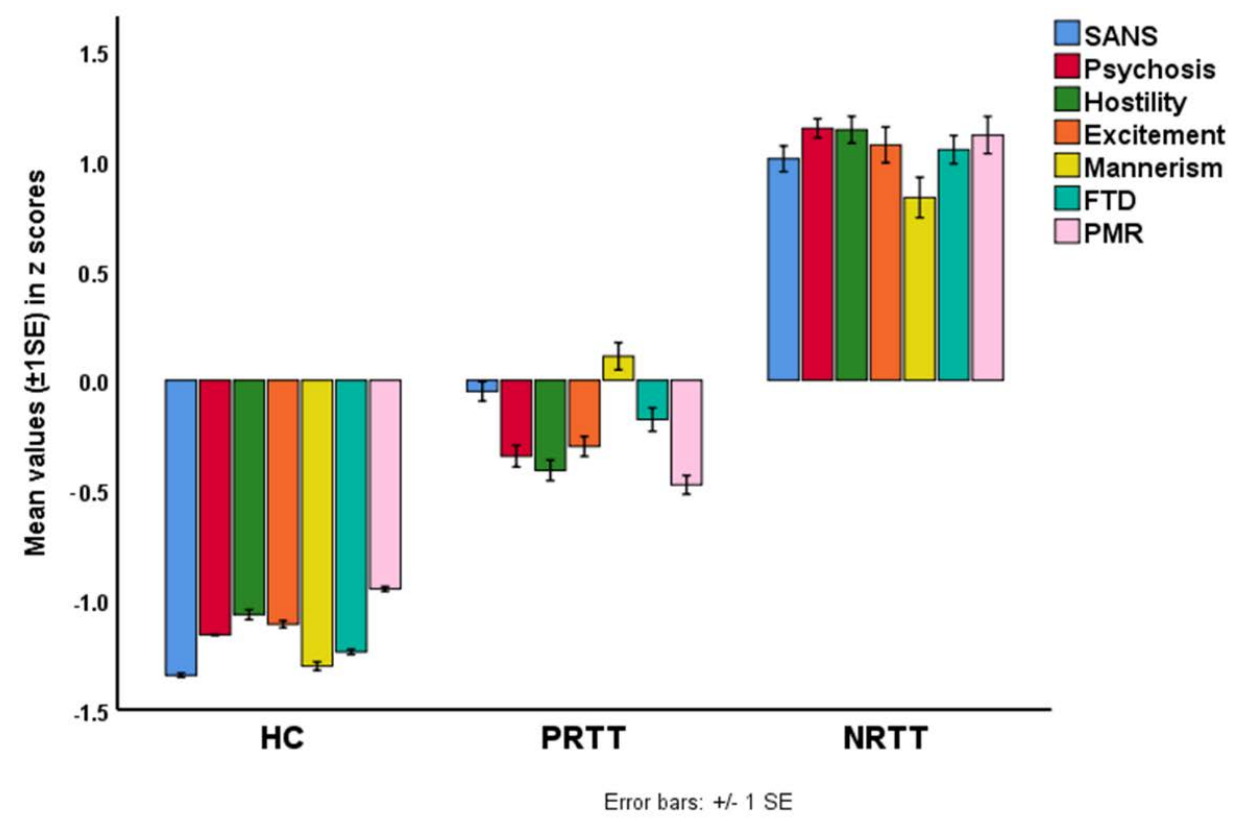

Figure 1. Bar plot showing the mean $( \pm 1 \mathrm{SE}) \mathrm{z}$ scores of psychosis, hostility, excitement, mannerism, formal thought disorders (FTD), psychomotor retardation (PMR) and the total score on the Scale for the Assessment of Negative Symptoms (SANS) in healthy controls (HC), partial responders to treatment (PRTT) and non-responders to treatment (NRTT).

Table 3. Results of multivariate GLM analysis showing the associations between biomarkers and diagnosis while adjusting for background variables.

\begin{tabular}{|c|c|c|c|c|c|c|}
\hline Type & Dependent Variables & $\begin{array}{c}\text { Explanatory } \\
\text { Variables }\end{array}$ & $\mathbf{F}$ & df & $p$ & Partial $\eta^{2}$ \\
\hline \multirow{4}{*}{ Multivariate } & \multirow{4}{*}{$\begin{array}{c}\beta \text {-Endorphin, } \\
\text { Endomorphin 2, KOR, } \\
\text { MOR, IL-6, IL-10 }\end{array}$} & Diagnosis & 6.68 & $12 / 296$ & $<0.001$ & 0.213 \\
\hline & & Sex & 1.23 & $6 / 147$ & 0.296 & 0.048 \\
\hline & & Age & 1.14 & $6 / 147$ & 0.341 & 0.045 \\
\hline & & BMI & 0.68 & $6 / 147$ & 0.667 & 0.027 \\
\hline \multirow{6}{*}{$\begin{array}{c}\text { Tests for } \\
\text { between-subject } \\
\text { effects }\end{array}$} & $\beta$-Endorphin & Diagnosis & 4.25 & $2 / 152$ & 0.016 & 0.053 \\
\hline & Endomorphin 2 & Diagnosis & 13.44 & $2 / 152$ & $<0.001$ & 0.150 \\
\hline & KOR & Diagnosis & 13.38 & $2 / 152$ & $<0.001$ & 0.150 \\
\hline & MOR & Diagnosis & 14.71 & $2 / 152$ & $<0.001$ & 0.162 \\
\hline & IL-6 & Diagnosis & 15.22 & $2 / 152$ & $<0.001$ & 0.167 \\
\hline & IL-10 & Diagnosis & 3.56 & $2 / 152$ & 0.031 & 0.045 \\
\hline
\end{tabular}

Diagnosis: partial responders to treatment versus non-responders to treatment versus healthy controls. BMI: body mass index; IL: interleukin; KOR: $\mathrm{k}$-opioid receptor; MOR: $\mu$-opioid receptor.

Table 5 shows the results of two binary logistic regression analyses examining the best predictors of SCZ (versus controls) and NRTT (versus PRTT) using an automatic stepwise method with biomarkers as explanatory variables while allowing for the effects of age, sex and education. The first regression analysis showed that SCZ was best explained by increased levels of endomorphin 2, KOR, and IL-10 $\left(\chi^{2}=39.338, \mathrm{df}=3, p<0.001\right.$, Nagelkerke $\left.=0.319\right)$ with an accuracy of $72.2 \%$, sensitivity of $74.8 \%$ and specificity of $65.1 \%$. The second regression shows that the combination of endomorphin 2 , MOR, and IL- 6 best discriminated NRTT from PRTT $\left(\chi^{2}=34.47, \mathrm{df}=3, p<0.001\right.$, Nagelkerke $\left.=0.346\right)$ with an accuracy of $72.2 \%$, sensitivity of $80.0 \%$ and a specificity of $76.5 \%$. 
Table 4. Model-generated estimated marginal means values (SE) of the biomarkers in partial responders to treatment (PRTT), non-responders to treatment (NRTT) and healthy controls (HC).

\begin{tabular}{cccc}
\hline Biomarkers & HC $^{\text {A }}$ & PRTT $^{\text {B }}$ & NRTT $^{\text {C }}$ \\
\hline B-Endorphin $(\mathrm{pg} / \mathrm{mL})$ & $20.37(2.52)$ & $16.57(2.32)^{\mathrm{C}}$ & $24.62(2.14)^{\mathrm{B}}$ \\
\hline Endomorphin 2 $(\mathrm{pg} / \mathrm{mL})$ & $256.84(39.69)^{\mathrm{B}, \mathrm{C}}$ & $315.77(36.61)^{\mathrm{A}, \mathrm{C}}$ & $478.08(33.71)^{\mathrm{A}, \mathrm{B}}$ \\
\hline $\mathrm{KOR}(\mathrm{ng} / \mathrm{mL})$ & $4.24(1.07)^{\mathrm{B}, \mathrm{C}}$ & $7.70(0.98)^{\mathrm{A}}$ & $7.32(0.91)^{\mathrm{A}}$ \\
\hline $\mathrm{MOR}(\mathrm{pg} / \mathrm{mL})$ & $3.03(0.36)^{\mathrm{C}}$ & $3.59(0.34)^{\mathrm{C}}$ & $4.85(0.31)^{\mathrm{A}, \mathrm{B}}$ \\
\hline $\mathrm{IL}-6(\mathrm{pg} / \mathrm{mL})$ & $4.82(0.86)^{\mathrm{C}}$ & $5.73(0.80)^{\mathrm{C}}$ & $7.79(0.73)^{\mathrm{A}, \mathrm{B}}$ \\
\hline $\mathrm{IL}-10(\mathrm{pg} / \mathrm{mL})$ & $10.83(0.87)^{\mathrm{C}}$ & $12.59(0.80)$ & $14.12(0.74)^{\mathrm{A}}$ \\
\hline
\end{tabular}

Table 5. Results of two different binary logistic regression analyses with schizophrenia (versus healthy controls) and non-responders to treatment (NRTT) versus partial responders to treatment (PRTT) as dependent variables and the biomarkers as explanatory variables.

\begin{tabular}{ccccccccc}
\hline Dichotomies & $\begin{array}{c}\text { Explanatory } \\
\text { Variables }\end{array}$ & B & SE & Wald & df & $p$ & OR & 95\% CI \\
\hline \multirow{2}{*}{$\begin{array}{c}\text { Schizophrenia/ } \\
\text { Controls }\end{array}$} & Endomorphin 2 & 0.496 & 0.237 & 4.386 & 1 & 0.036 & 1.642 & $1.032-2.61$ \\
\cline { 2 - 8 } & KOR & 0.979 & 0.280 & 12.231 & 1 & $<0.001$ & 2.663 & $1.538-4.61$ \\
\cline { 2 - 8 } & IL-10 & 0.591 & 0.225 & 6.902 & 1 & 0.009 & 1.806 & $1.162-2.81$ \\
\hline \multirow{3}{*}{ NRTT/PRTT } & Endomorphin 2 & 0.711 & 0.261 & 7.434 & 1 & 0.006 & 2.037 & $1.22-3.40$ \\
\cline { 2 - 8 } & MOR & 0.673 & 0.260 & 6.705 & 1 & 0.010 & 1.960 & $1.18-3.26$ \\
\cline { 2 - 8 } & IL-6 & 0.757 & 0.258 & 8.600 & 1 & 0.003 & 2.132 & $1.29-3.54$
\end{tabular}

B: logistic regression coefficient, OR: Odds ratio, 95\% CI: 95\% confidence intervals. IL: interleukin; KOR: K-opioid receptor; MOR: $\mu$-opioid receptor.

\subsection{Effects of Background Variables}

As shown above, age, sex, and BMI had no significant effects on serum biomarker levels. TUD also had no significant effect on the measured biomarker levels $(\mathrm{F}=0.19, \mathrm{df}=6 / 146, p=0.979$, partial $\left.\eta^{2}=0.008\right)$. We also examined the effects of antipsychotic drug administration using multivariate GLM analysis and tests for between-subjects. We found no significant effects of use of clozapine $(\mathrm{F}=0.63$, $\mathrm{df}=6 / 146, p=0.704$, partial $\left.\eta^{2}=0.025\right)$, haloperidol $\left(\mathrm{F}=0.88, \mathrm{df}=6 / 146, p=0.513\right.$, Partial $\left.\eta^{2}=0.035\right)$, risperidone $\left(\mathrm{F}=0.92, \mathrm{df}=6 / 146, p=0.484\right.$, partial $\left.\eta^{2}=0.036\right)$, and quetiapine $(\mathrm{F}=0.93, \mathrm{df}=6 / 146$, $p=0.476$, partial $\left.\eta^{2}=0.037\right)$. However, use of olanzapine had a significant effect on the measured biomarkers $\left(\mathrm{F}=2.89, \mathrm{df}=6 / 146, p=0.011\right.$, partial $\left.\eta^{2}=0.106\right)$, although after $\mathrm{p}$-correction for multiple testing this effect was no longer significant $(p=0.195)$.

\subsection{Prediction of Symptom Domains by Biomarkers}

Table 6 shows different stepwise multiple regression analyses with the symptom domains as dependent variables and the six biomarkers as explanatory variables while allowing for the effects of education, age and sex. Regression \#1 shows that $28.0 \%$ of the variance in the total SANS score was explained by the regression on endomorphin 2, MOR, and IL-6. Regressions \#2, \#3, \#4 and \#5 show that the same variables explained a considerable part of the variance in psychosis $(28.3 \%$, but additionally with education), hostility (26.9\%), excitation (22.4\%), and PMR (28.4\%). Regression \#6 shows that $23.7 \%$ of the variance in mannerism was explained by endomorphin 2, MOR, KOR, and IL-10. Regression \#7 shows that $27.8 \%$ of the variance in FTD was explained by the combined effects of endomorphin 2 , MOR, IL-6, IL-10, and education. Partial correlation coefficients (adjusted for age, sex, and education) showed that all symptom profiles were significantly associated with plasma KOR kevels (all $\mathrm{r}>0.314$, $p<0.001, n=153)$, but not with $\beta$-endorphin. 
Table 6. Results of multiple regression analysis with schizophrenia symptom domains as dependent variables.

\begin{tabular}{|c|c|c|c|c|c|c|c|c|}
\hline Dependent Variables & Explanatory Variables & $\beta$ & $\mathbf{t}$ & $p$ & $F_{\text {model }}$ & df & $p$ & $\mathbf{R}^{2}$ \\
\hline \multirow{4}{*}{$\# 1$. SANS } & Model & & & & \multirow{4}{*}{19.94} & \multirow{4}{*}{$3 / 154$} & \multirow{4}{*}{$<0.001$} & \multirow{4}{*}{0.280} \\
\hline & Endomorphin 2 & 0.302 & 4.290 & $<0.001$ & & & & \\
\hline & MOR & 0.268 & 3.724 & $<0.001$ & & & & \\
\hline & IL-6 & 0.191 & 2.600 & 0.010 & & & & \\
\hline \multirow{5}{*}{ \#2. Psychosis } & Model & & & & \multirow{5}{*}{15.13} & \multirow{5}{*}{$4 / 153$} & \multirow{5}{*}{$<0.001$} & \multirow{5}{*}{0.283} \\
\hline & Endomorphin 2 & 0.259 & 3.674 & $<0.001$ & & & & \\
\hline & MOR & 0.263 & 3.644 & $<0.001$ & & & & \\
\hline & IL-6 & 0.188 & 2.511 & 0.013 & & & & \\
\hline & Education & -0.157 & -2.248 & 0.026 & & & & \\
\hline \multirow{4}{*}{ \#3. Hostility } & Model & & & & \multirow{4}{*}{18.91} & \multirow{4}{*}{$3 / 154$} & \multirow{4}{*}{$<0.001$} & \multirow{4}{*}{0.269} \\
\hline & Endomorphin 2 & 0.246 & 3.460 & 0.001 & & & & \\
\hline & MOR & 0.270 & 3.724 & $<0.001$ & & & & \\
\hline & IL-6 & 0.231 & 3.128 & 0.002 & & & & \\
\hline \multirow{4}{*}{ \#4. Excitation } & Model & & & & \multirow{4}{*}{14.82} & \multirow{4}{*}{$3 / 154$} & \multirow{4}{*}{$<0.001$} & \multirow{4}{*}{0.224} \\
\hline & Endomorphin 2 & 0.218 & 2.984 & 0.003 & & & & \\
\hline & MOR & 0.248 & 3.314 & 0.001 & & & & \\
\hline & IL-6 & 0.215 & 2.822 & 0.005 & & & & \\
\hline \multirow{4}{*}{ \#5. PMR } & Model & & & & \multirow{4}{*}{20.39} & \multirow{4}{*}{$3 / 154$} & \multirow{4}{*}{$<0.001$} & \multirow{4}{*}{0.284} \\
\hline & Endomorphin 2 & 0.310 & 4.412 & $<0.001$ & & & & \\
\hline & MOR & 0.223 & 3.104 & 0.002 & & & & \\
\hline & IL-6 & 0.233 & 3.189 & 0.002 & & & & \\
\hline \multirow{5}{*}{ \#6. Mannerism } & Model & & & & \multirow{5}{*}{11.91} & \multirow{5}{*}{$4 / 153$} & & \\
\hline & Endomorphin 2 & 0.170 & 2.252 & 0.026 & & & & \\
\hline & MOR & 0.183 & 2.310 & 0.022 & & & $<0.001$ & 0.237 \\
\hline & KOR & 0.211 & 2.613 & 0.010 & & & & \\
\hline & IL-10 & 0.199 & 2.710 & 0.008 & & & & \\
\hline & Model & & & & & & & \\
\hline & Endomorphin 2 & 0.203 & 2.850 & 0.005 & & & & \\
\hline \#7. FTD & MOR & 0.246 & 3.285 & 0.001 & 1171 & $5 / 152$ & $<0 \cap 01$ & 0278 \\
\hline \#7. FID & IL-6 & 0.168 & 2.223 & 0.028 & 11.71 & & $<0.001$ & 0.278 \\
\hline & Education & -0.159 & -2.254 & 0.026 & & & & \\
\hline & IL-10 & 0.147 & 2.047 & 0.042 & & & & \\
\hline
\end{tabular}

$\beta$ : standardized regression coefficient, IL: interleukin; KOR: K-opioid receptor; MOR: $\mu$-opioid receptor. SANS: Scale for the Assessment of Negative Symptoms; FTD: formal thought disorders; PMR: psychomotor retardation, t: t-statistic value, F: F-statistic value, df: degree of freedom, and \#: number of regression analysis.

\subsection{Prediction of Cognitive Impairments by Biomarkers}

Table 7 shows the outcome of six multiple regression analyses with the cognitive test results as dependent variables and biomarkers as explanatory variables while allowing for the effects of age, sex and education. We found that (regression \#1) 16.3\% of the variance in List Learning scores was explained by the regression on IL-6 and MOR (all inversely associated). Up to $21.4 \%$ of the variance in Digit Sequencing Task scores (regression \#2) was explained by the combined effects of MOR, IL-6, endomorphin 2 (inversely) and education (positively). Part of the variance (20.2\%) in Category Instances test scores (regression \#3) was explained by MOR, endomorphin 2 (negatively) and education (positively). We found that $28.3 \%$ of the variance in the Controlled Oral Word Association Test (COWA) test scores (regression \#4) was explained by the cumulative effects of MOR, IL-6, endomorphin 2, and age (negatively) while $22.9 \%$ of the variance in symbol coding scores (\#5) was negatively associated with KOR, IL-10, and endomorphin 2. Up to $29.3 \%$ of the variance in Tower of London test scores 
(regression \#6) was explained by the combined effects of MOR, IL-6, endomorphin 2, sex (all inversely) and education (positively). Partial correlation coefficients (adjusted for age, sex, and education) showed that all cognitive tests results were significantly associated with plasma KOR (all $\mathrm{r}>0.206, p<0.01$, $n=152$ ), but not with $\beta$-endorphin.

Table 7. Results of multiple regression analysis with neurocognitive test scores as dependent variables.

\begin{tabular}{|c|c|c|c|c|c|c|c|c|}
\hline Dependent Variables & Explanatory Variables & $\beta$ & $\mathbf{t}$ & $p$ & $F_{\text {model }}$ & df & $p$ & $R^{2}$ \\
\hline \multirow{3}{*}{ \#1. List learning } & Model & & & & \multirow{3}{*}{15.08} & \multirow{3}{*}{ 2/155 } & \multirow{3}{*}{$<0.001$} & \multirow{3}{*}{0.163} \\
\hline & MOR & 0.304 & 3.945 & $<0.001$ & & & & \\
\hline & IL-6 & 0.188 & 2.441 & 0.016 & & & & \\
\hline \multirow{5}{*}{ \#2. Digit sequencing task } & Model & & & & \multirow{5}{*}{10.43} & \multirow{5}{*}{$4 / 153$} & \multirow{5}{*}{$<0.001$} & \multirow{5}{*}{0.214} \\
\hline & MOR & 0.224 & 2.965 & 0.004 & & & & \\
\hline & IL-6 & 0.190 & 2.431 & 0.016 & & & & \\
\hline & Endomorphin 2 & 0.158 & 2.143 & 0.034 & & & & \\
\hline & Education & 0.188 & 2.575 & 0.011 & & & & \\
\hline \multirow{4}{*}{ \#3. Category instances } & Model & & & & \multirow{4}{*}{13.03} & \multirow{4}{*}{$3 / 154$} & \multirow{4}{*}{$<0.001$} & \multirow{4}{*}{0.202} \\
\hline & MOR & 0.283 & 3.891 & $<0.001$ & & & & \\
\hline & Endomorphin 2 & 0.246 & 3.379 & 0.001 & & & & \\
\hline & Education & 0.192 & 2.672 & 0.008 & & & & \\
\hline \multirow{5}{*}{ \#4. COWA } & Model & & & & \multirow{5}{*}{15.12} & \multirow{5}{*}{$4 / 153$} & \multirow{5}{*}{$<0.001$} & \multirow{5}{*}{0.283} \\
\hline & MOR & 0.293 & 4.070 & $<0.001$ & & & & \\
\hline & IL-6 & 0.183 & 2.497 & 0.014 & & & & \\
\hline & Endomorphin 2 & 0.259 & 3.669 & $<0.001$ & & & & \\
\hline & Age & 0.161 & 2.376 & 0.019 & & & & \\
\hline \multirow{4}{*}{ \#5. Symbol coding } & Model & & & & \multirow{4}{*}{15.15} & \multirow{4}{*}{$3 / 153$} & \multirow{4}{*}{$<0.001$} & \multirow{4}{*}{0.229} \\
\hline & KOR & 0.306 & 4.013 & $<0.001$ & & & & \\
\hline & IL-10 & 0.201 & 2.826 & 0.005 & & & & \\
\hline & Endomorphin 2 & 0.201 & 2.647 & 0.009 & & & & \\
\hline \multirow{6}{*}{ \#6. Tower of London } & Model & & & & \multirow{6}{*}{12.61} & \multirow{6}{*}{$5 / 152$} & \multirow{6}{*}{$<0.001$} & \multirow{6}{*}{0.293} \\
\hline & MOR & 0.273 & 3.783 & $<0.001$ & & & & \\
\hline & IL-6 & 0.150 & 2.007 & 0.046 & & & & \\
\hline & Endomorphin 2 & 0.146 & 2.070 & 0.040 & & & & \\
\hline & Sex & 0.183 & 2.656 & 0.009 & & & & \\
\hline & Education & 0.290 & 4.178 & $<0.001$ & & & & \\
\hline
\end{tabular}

COWA: Controlled Oral Word Association Test; IL: interleukin; KOR: -opioid receptor; MOR: $\mu$-opioid receptor. FTD: formal thought disorders; PMR: psychomotor retardation; SANS: Scale for the assessment of negative symptoms, $\beta$ : standardized regression coefficient with t-statistic and $\mathrm{p}$-value, F: F-statistic value, df: degree of freedom, and \#: number of regression analysis.

\section{Discussion}

The first major finding of this study is that serum levels of KOR, MOR, endomorphin 2, IL-6 and IL-10 are significantly increased in SCZ as compared with controls. This is a first report on increased endomorphin 2 levels in SCZ. Volk et al. found that increased MOR mRNA and protein levels in SCZ are largely independent of illness severity, suggesting that increased MOR expression is part of the disease process rather than a consequence of illness chronicity [41]. In Han Chinese, a MOR polymorphism may confer risk for SCZ [42] while an A118G polymorphism of the MOR gene was associated with SCZ [43]. One study reported lowered MOR availability in the brain of SCZ patients who died as a result of suicide, which would be consistent with increased levels of EOS peptides occupying those receptors [44]. Our negative findings on $\beta$-endorphin levels in SCZ are not in agreement with those of a previous report [42]. Animal models of SCZ are accompanied by moderate alterations in EOS peptides $[24,25,28,41]$. Our findings on increased IL-6 and IL-10 levels in SCZ are in agreement with previous reports that SCZ is accompanied by enhanced IRS and CIRS functions [8]. 
This is also a first report that a non-response to treatment is characterized by increased MOR, endomorphin 2 and $\beta$-endorphin levels, indicating that the EOS participates in the pathophysiology of treatment resistance. Our findings that IL-6 is increased in NRTT as compared with PRTT is in accordance with previous reports that IL-6 and macrophage M1 activation are associated with TRS $[8,15]$. In the current study we found that serum IL-10 was significantly higher in NRTT than in controls, whereas PRTT occupied an intermediate position. Previous reports showed that TRS is accompanied by increased IL-10 levels [45].

The second major finding of this study is that IL-6 levels are strongly associated with all four EOS biomarkers whilst IL-10 is associated with MOR concentrations only. Similar findings were reported in major depression showing significant associations between an immune activation index (based on IL-6 and IL-10) and KOR, MOR and $\beta$-endorphin levels $[5,30]$. Many inflammatory diseases are associated with up-regulation of opioid receptors [46] and, in those conditions, inflammation is associated with increased MOR sensitivity in the periphery and in the brainstem [47]. Moreover, the combination of IL-6 with endomorphin 2 and MOR yielded a highly significant discrimination of NRTT from PRTT indicating that upregulation of the immune-EOS axis is associated with the pathophysiology of a non-response to treatment.

During activation of the IRS, immune cells produce a) opioid peptides, [48,49] with increased EO concentrations in blood and inflammatory sites [50]. MOR and KOR are widely distributed on peripheral blood immune cells [51-56] while the expression of the MOR gene in immune and neuronal cells is enhanced by pro-inflammatory signals including IL-1 $\beta$, IL-6 and TNF- $\alpha$ [57]. Moreover, LPS, which is increased in deficit schizophrenia [58], increases MOR transcription in macrophages via oxidative stress signals [59]. As such, proliferation and activation of immune cells may be accompanied with increased expression of opioid receptors while the toxic effects of inflammatory and oxidative stress mechanisms may damage cell membranes thereby increasing shedding of the opioid receptors into the plasma. Some T-cell subsets release cytokines and EOS peptides/receptors that can promote, suppress, or resolve pain [60,61]. Moreover, also endomorphin 2 may be produced by immunocytes in inflamed subcutaneous tissues, whereas this peptide is almost absent in non-inflamed tissue [62]. In addition, MOR is expressed in macrophages and neutrophils, indicating that endomorphins produced during inflammation can stimulate MORs on the surface of these cells [63]. As such, the positive intercorrelations detected in our study between increased IL- 6 levels and EOS biomarkers, including endomorphin 2, suggest that the enhanced IRS/CIRS responses in SCZ patients and especially in NRTT are accompanied by increased production of EOS biomarkers. This may be important to brain functions as some EOS peptides including endomorphin 2 may cross the blood-brain barrier (BBB) following intraperitoneal administration [64]. Ting et al. (1997) reported that increased MOR/KOR binding on the BBB precedes BBB disruption [65]. Moreover, recent research shows that SCZ and especially deficit $S C Z$ is accompanied by a breakdown of the tight junction and vascular barriers of the BBB [66].

There is now evidence that the EOS exerts immune-regulatory activities through multiple feedback loops $[67,68]$. For example, EOS peptides/receptors modulate adaptive immune functions including attenuating Th functions and neutrophil chemotaxis [69,70], increasing T cell apoptosis [70] and levels of immune-regulatory cytokines including IL-10 [71]. Increased MOR, KOR and $\beta$-endorphin levels display negative immune-regulatory properties as reviewed in [68]. Therefore, the latter authors concluded that, in major depression, increased dynorphin/KOR and $\beta$-endorphin/MOR signaling may contribute to CIRS functions [68]. In addition, endomorphin 2 may regulate neutrophil, macrophage and microglia functions even at ultra-low concentrations [72]. Yang et al. (2012) reported that activated dendritic cells induce their expression and secretion of endomorphins and that the latter, in turn, may suppress T lymphocyte proliferation through stimulation of MOR [73]. Endomorphin 2 not only regulates the production of pro-inflammatory cytokines, but also inhibits macrophage chemotaxis and the production of reactive oxygen species (ROS) by macrophages and neutrophils [72,74]. Importantly, in other inflammatory disorders, endomorphins exert anti-inflammatory actions $[75,76]$ for example by 
inhibiting IL-8, but not IL-6 [76]. Moreover, endomorphin 2 is advocated as an agent to treat chronic inflammatory disease [75]. As such, all four EOS biomarkers measured here are produced by activated immunocytes and may, consequently, exert CIRS activities thereby regulating the immune response in SCZ patients and NRTT.

The third major finding of this study is that MOR, KOR and endomorphin 2 were associated with PHEMN (psychosis, hostility, excitation, mannerism, negative) symptoms, psychomotor retardation and formal thought disorders as well as neurocognitive deficits in memory, attention and executive functions. The detrimental effects of IL-6 and, especially, IL-6 trans-signaling on brain functions including neurocognitive functions are well established [77-79]. Although the EOS may exert CIRS (see above discussion) and neuroprotective effects [73], this system may have detrimental effects as well. For example, endomorphins may activate immune pathways, which may result in more detrimental effects, including increased IL-1 $\beta$ signaling, macrophage adhesion, expression of adhesion molecules on macrophages, and neutrophil chemotaxis [72,74].

Moreover, KOR agonists may exhibit psychotomimic properties while opioid antagonists may ameliorate SCZ symptoms [80]. KOR activation and administration of KOR agonists including salvinorin A may induce hallucinations, anxiety, depression, negative-like symptoms (lack of motivation and social withdrawal), psychomotor retardation, dysphoria and neurocognitive impairments including in attention, working memory and task performance, which are quite similar to the effects of acute ketamine administration [81-83]. These effects were explained by attenuated glutamate and dopamine release in the prefrontal cortex, which play a key role in neuropsychological functioning [84,85]. Therefore, increased KOR expression as observed in our study may play a role in the pathophysiology of SCZ.

Moreover, endomorphin 2 may stimulate postsynaptic MORs causing postsynaptic hyperpolarization of excitatory interneurons [86,87]. Endomorphin 2 may additionally induce excitation, a bell-shaped dose-response curve for locomotor enhancement and aversive effects, and place aversion [88]. As such, increased endomorphin 2 levels could, combined with increased KOR, contribute to the pathophysiology of a non-response to treatment.

This study should be interpreted with regard to its limitations. First, this is a case control study and, therefore, no firm conclusions can be drawn on causal relationships. Second, it would have been even more interesting if we had measured other IRS and CIRS cytokines and endomorphin 1. Nevertheless, here we assayed endomorphin 2 as it may have additional functions with regard to the pathophysiology of schizophrenia as compared with endomorphin 1 including effects on the release of dynorphin A and [Met]enkephalin, and the consequent activation of KOR- and delta-opioid receptors [89,90]. Moreover, dynorphin released in response to endomorphin 2 has a major role in immune cell functions [91]. Third, the genes encoding endomorphin 1 and 2 have not yet been identified [92], although it is suggested that endomorphins may be synthesized enzymatically, by a non-ribosomal mechanism [93]. Fourth, it is plausible that mass spectrometry may be more suitable and reliable to detect endomorphin 2 levels as compared with ELISA measurements, although enzyme immunoassay kits may detect low endomorphin 2 levels in rodent plasma and cerebro-spinal fluid [94].

\section{Conclusions}

Serum levels of EOS biomarkers including endomorphin-2, MOR, KOR, IL-6 and IL-10 are increased in SCZ patients as compared with controls, while increased endomorphin 2, MOR, and IL-6 are biomarker features of a non-response to treatment. The findings indicate that changes in the EOS and immune-EOS interactions play a role in the pathophysiology of SCZ and a non-response to treatment.

Author Contributions: All the contributing authors have participated in the preparation of the manuscript. H.K.A.-H., S.R.M., A.H.A.-D. and M.M. conceived and designed the experiments; H.K.A.-H., K.F.A.-R. and S.R.M. performed the experiments; M.M. and T.S., and D.S. analyzed the data; M.M., H.K.A.-H., T.S. and D.S. wrote the paper. All authors have read and agreed to the published version of the manuscript. 
Funding: This research received no external funding.

Acknowledgments: We acknowledge the staff of the Psychiatry Unit at Al-Imam Al-Hussain Medical City in Karbala city for their help in the collection of samples and the high-skilled staff members of Asia Clinical Laboratory, Najaf city, for their help in the assays.

Conflicts of Interest: The authors declare no conflict of interest.

\section{Abbreviations}

$\begin{array}{ll}\text { SCZ } & \text { schizophrenia } \\ \text { IRS } & \text { immune-inflammatory response system } \\ \text { IL } & \text { Interleukin } \\ \text { TNF } & \text { tumor necrosis factor } \\ \text { Th } & \text { T helper } \\ \text { CIRS } & \text { compensatory immune regulatory system } \\ \text { TRS } & \text { treatment resistant schizophrenia } \\ \text { NRTT } & \text { non-responders to treatment } \\ \text { EO } & \text { endogenous opioids } \\ \text { MOR } & \text { mu-opioid receptor } \\ \text { KOR } & \text { kappa-opioid receptor } \\ \text { EOS } & \text { endogenous opioid system } \\ \text { PRTT } & \text { partial responders to treatment } \\ \text { CGI } & \text { Clinical Global Impression } \\ \text { CRP } & \text { C reactive protein } \\ \text { MINI } & \text { Mini-International Neuropsychiatric Interview } \\ \text { CGI-I } & \text { CGI Improvement } \\ \text { CGI-S } & \text { CGI Severity } \\ \text { SANS } & \text { the Scale for the Assessments of Negative Symptoms } \\ \text { FTD } & \text { formal thought disorders } \\ \text { PMR } & \text { psychomotor retardation } \\ \text { BPRS } & \text { Brief Psychiatric Rating Scale } \\ \text { PANNS } & \text { Positive and Negative Syndrome Scale } \\ \text { BACS } & \text { Brief Assessment of Cognition in Schizophrenia } \\ \text { TUD } & \text { tobacco use disorder } \\ \text { BMI } & \text { body mass index } \\ \text { GLM } & \text { generalized linear model } \\ & \text { Com }\end{array}$

\section{References}

1. Smith, R.S.; Maes, M. The macrophage-T-lymphocyte theory of schizophrenia: Additional evidence. Med. Hypotheses 1995, 45, 135-141. [CrossRef]

2. Noto, C.; Maes, M.; Ota, V.K.; Teixeira, A.L.; Bressan, R.A.; Gadelha, A.; Brietzke, E. High predictive value of immune-inflammatory biomarkers for schizophrenia diagnosis and association with treatment resistance. World J. Biol. Psychiatry 2015, 16, 422-429. [CrossRef]

3. Rubesa, G.; Gudelj, L.; Makovac, D. J Immunological characteristics of schizophrenia. Psychiatr. Danub. 2018, 30, 180-187. [PubMed]

4. Al-Hakeim, H.K.; Almulla, A.F.; Maes, M. The neuroimmune and neurotoxic fingerprint of major neurocognitive psychosis or deficit schizophrenia: A supervised machine learning study. Neurotox. Res. 2020, 37, 753-771. [CrossRef] [PubMed]

5. Almulla, A.F.; Al-Hakeim, H.K.; Abed, M.S.; Carvalho, A.F.; Maes, M. Chronic fatigue and fibromyalgia symptoms are key components of deficit schizophrenia and are strongly associated with activated immune-inflammatory pathways. Schizophr. Res. 2020. [CrossRef] [PubMed] 
6. Maes, M.; Sirivichayakul, S.; Matsumoto, A.K.; Maes, A.; Michelin, A.P.; de Oliveira Semeão, L.; de Lima Pedrão, J.V.; Moreira, E.G.; Barbosa, D.S.; Geffard, M. Increased Levels of Plasma Tumor Necrosis Factor- $\alpha$ Mediate Schizophrenia Symptom Dimensions and Neurocognitive Impairments and Are Inversely Associated with Natural IgM Directed to Malondialdehyde and Paraoxonase 1 Activity. Mol. Neurobiol. 2020, 57, 2333-2345. [CrossRef]

7. Noto, M.N.; Maes, M.; Nunes, S.O.V.; Ota, V.K.; Rossaneis, A.C.; Verri, W.A., Jr.; Cordeiro, Q.; Belangero, S.I.; Gadelha, A.; Bressan, R.A. Activation of the immune-inflammatory response system and the compensatory immune-regulatory system in antipsychotic naive first episode psychosis. Eur. Neuropsychopharmacol. 2019, 29, 416-431. [CrossRef]

8. Roomruangwong, C.; Noto, C.; Kanchanatawan, B.; Anderson, G.; Kubera, M.; Carvalho, A.F.; Maes, M. The role of aberrations in the immune-inflammatory response system (IRS) and the compensatory immune-regulatory reflex system (CIRS) in different phenotypes of schizophrenia: The IRS-CIRS theory of schizophrenia. Mol. Neurobiol. 2020, 57, 778-797. [CrossRef] [PubMed]

9. Kanchanatawan, B.; Hemrungrojn, S.; Thika, S.; Sirivichayakul, S.; Ruxrungtham, K.; Carvalho, A.F.; Geffard, M.; Anderson, G.; Maes, M. Changes in tryptophan catabolite (TRYCAT) pathway patterning are associated with mild impairments in declarative memory in schizophrenia and deficits in semantic and episodic memory coupled with increased false-memory creation in deficit schizophrenia. Mol. Neurobiol. 2018, 55, 5184-5201. [CrossRef] [PubMed]

10. Maes, M.; Sirivichayakul, S.; Kanchanatawan, B.; Carvalho, A.F. In schizophrenia, psychomotor retardation is associated with executive and memory impairments, negative and psychotic symptoms, neurotoxic immune products and lower natural IgM to malondialdehyde. World J. Biol. Psychiatry 2020, 21, 383-401. [CrossRef] [PubMed]

11. Al-Hakeim, H.K.; Al-Rammahi, D.A.; Al-Dujaili, A.H. IL-6, IL-18, sIL-2R, and TNF $\alpha$ proinflammatory markers in depression and schizophrenia patients who are free of overt inflammation. J. Affect. Disord. 2015, 182, 106-114. [CrossRef] [PubMed]

12. Maes, M.; Vojdani, A.; Geffard, M.; Moreira, E.G.; Barbosa, D.S.; Michelin, A.P.; de Oliveira Semeão, L.; Sirivichayakul, S.; Kanchanatawan, B. Schizophrenia phenomenology comprises a bifactorial general severity and a single-group factor, which are differently associated with neurotoxic immune and immune-regulatory pathways. Biomol. Concepts 2019, 10, 209-225. [CrossRef] [PubMed]

13. Sirivichayakul, S.; Kanchanatawan, B.; Thika, S.; Carvalho, A.F.; Maes, M. A New Schizophrenia Model: Immune Activation is Associated with the Induction of Different Neurotoxic Products which Together Determine Memory Impairments and Schizophrenia Symptom Dimensions. CNS Neurol. Disord. Drug Targets 2019, 18, 124-140. [CrossRef] [PubMed]

14. Sirivichayakul, S.; Kanchanatawan, B.; Thika, S.; Carvalho, A.F.; Maes, M. Eotaxin, an endogenous cognitive deteriorating chemokine (ECDC), is a major contributor to cognitive decline in normal people and to executive, memory, and sustained attention deficits, formal thought disorders, and psychopathology in schizophrenia patients. Neurotox. Res. 2019, 35, 122-138.

15. Maes, M.; Chiavetto, L.B.; Bignotti, S.; Tura, G.-J.B.; Pioli, R.; Boin, F.; Kenis, G.; Bosmans, E.; De Jongh, R.; Lin, A. Effects of atypical antipsychotics on the inflammatory response system in schizophrenic patients resistant to treatment with typical neuroleptics. Eur. Neuropsychopharmacol. 2000, 10, 119-124. [CrossRef]

16. Charles, S.J.; Farias, M.; Dunbar, R.I. The aetiology of social deficits within mental health disorders: The role of the immune system and endogenous opioids. Brain Behav. Immun. Health 2020, 1, 100003. [CrossRef]

17. Corder, G.; Castro, D.C.; Bruchas, M.R.; Scherrer, G. Endogenous and exogenous opioids in pain. Annu. Rev. Neurosci. 2018, 41, 453-473. [CrossRef]

18. Plein, L.M.; Rittner, H.L. Opioids and the immune system-friend or foe. Br. J. Pharmacol. 2018, 175, $2717-2725$. [CrossRef]

19. Li, Z.-H.; Chu, N.; Shan, L.-D.; Gong, S.; Yin, Q.-Z.; Jiang, X.H. Inducible expression of functional mu opioid receptors in murine dendritic cells. J. Neuroimmune Pharmacol. 2009, 4, 359-367. [CrossRef]

20. Hu, S.; Peterson, P.K.; Chao, C.C. Kappa-opioid modulation of human microglial cell superoxide anion generation. Biochem. Pharmacol. 1998, 56, 285-288. [CrossRef]

21. Sacerdote, P. Opioids and the immune system. Palliat. Med. 2006, 20, 9-15. [CrossRef] 
22. Finley, M.J.; Chen, X.; Bardi, G.; Davey, P.; Geller, E.B.; Zhang, L.; Adler, M.W.; Rogers, T. Bi-directional heterologous desensitization between the major HIV-1 co-receptor CXCR4 and the k-opioid receptor. J. Neuroimmunol. 2008, 197, 114-123. [CrossRef] [PubMed]

23. McLaughlin, P.J.; McHugh, D.P.; Magister, M.J.; Zagon, I.S. Endogenous opioid inhibition of proliferation of $\mathrm{T}$ and $\mathrm{B}$ cell subpopulations in response to immunization for experimental autoimmune encephalomyelitis. BMC Immunol. 2015, 16, 24. [CrossRef] [PubMed]

24. Schwarzer, C. 30 years of dynorphins-New insights on their functions in neuropsychiatric diseases. Pharmacol. Ther. 2009, 123, 353-370. [CrossRef] [PubMed]

25. Ashok, A.H.; Myers, J.; Marques, T.R.; Rabiner, E.A.; Howes, O.D. Reduced mu opioid receptor availability in schizophrenia revealed with [11 C]-carfentanil positron emission tomographic imaging. Nat. Commun 2019, 10, 1-9. [CrossRef] [PubMed]

26. Trezza, V.; Damsteegt, R.; Achterberg, E.M.; Vanderschuren, L. Nucleus accumbens $\mu$-opioid receptors mediate social reward. J. Neurosci. 2011, 31, 6362-6370. [CrossRef]

27. Urban-Kowalczyk, M.; Śmigielski, J.; Strzelecki, D. Comparison of beta-endorphin and CGRP levels before and after treatment for severe schizophrenia. Neuropsychiatr. Dis. Treat. 2016, 12, 863-868. [CrossRef]

28. Szúcs, E.; Büki, A.; Kékesi, G.; Horváth, G.; Benyhe, S. Mu-Opioid (MOP) receptor mediated G-protein signaling is impaired in specific brain regions in a rat model of schizophrenia. Neurosci. Lett. 2016, 619, 29-33. [CrossRef]

29. Fichna, J.; Janecka, A.; Costentin, J.; Do Rego, J.C. The endomorphin system and its evolving neurophysiological role. Pharmacol. Rev. 2007, 59, 88-123. [CrossRef]

30. Al-Hakeim, H.K.; Al-Fadhel, S.Z.; Al-Dujaili, A.H.; Maes, M. In major depression, increased kappa and mu opioid receptor levels are associated with immune activation. Acta Neuropsychiatr. 2020, 32, 99-108. [CrossRef]

31. Jenab, S.; Morris, P.L. Interleukin-6 regulation of kappa opioid receptor gene expression in primary sertoli cells. Endocrine 2000, 13, 11-15. [CrossRef]

32. Börner, C.; Kraus, J.; Schröder, H.; Ammer, H.; Höllt, V. Transcriptional regulation of the human $\mu$-opioid receptor gene by interleukin-6. Mol. Pharmacol. 2004, 66, 1719-1726. [CrossRef] [PubMed]

33. Wu, H.Y.; Mao, X.F.; Tang, X.Q.; Ali, U.; Apryani, E.; Liu, H.; Li, X.Y.; Wang, Y.X. Spinal interleukin-10 produces antinociception in neuropathy through microglial $\beta$-endorphin expression, separated from antineuroinflammation. Brain Behav. Immun. 2018, 73, 504-519. [CrossRef]

34. Guy, W. Clinical Global Impressions Scale (CGI). In Handbook of Psychiatric Measures; Rush, A.J., Ed.; American Psychiatric Association: Washington, DC, USA, 2000; pp. 100-102.

35. Andreasen, N.C. The Scale for the Assessment of Negative Symptoms (SANS): Conceptual and theoretical foundations. Br. J. Psychiatry Suppl. 1989, 155, 49-52. [CrossRef]

36. Overall, J.E.; Gorham, D.R. The brief psychiatric rating scale. Psychol. Rep. 1962, 10, 799-812. [CrossRef]

37. Hamilton, M.J. A rating scale for depression. J. Neurol. Neurosurg. Psychiat. 1960, 23, 56-62. [CrossRef]

38. Kay, S.R.; Fiszbein, A.; Opler, L.A. The positive and negative syndrome scale (PANSS) for schizophrenia. Schizophr. Bull. 1987, 13, 261-276. [CrossRef]

39. Keefe, R.S.; Goldberg, T.E.; Harvey, P.D.; Gold, J.M.; Poe, M.P.; Coughenour, L.J. The Brief Assessment of Cognition in Schizophrenia: Reliability, sensitivity, and comparison with a standard neurocognitive battery. Schizophr. Res. 2004, 68, 283-297. [CrossRef]

40. Almulla, A.F.; Al-Hakeim, H.K.; Maes, M. Schizophrenia phenomenology revisited: Positive and negative symptoms are strongly related reflective manifestations of an underlying single trait indicating overall severity of schizophrenia. CNS Spectr. 2020, 1-10. [CrossRef]

41. Volk, D.W.; Radchenkova, P.V.; Walker, E.M.; Sengupta, E.J.; Lewis, D.A. Cortical opioid markers in schizophrenia and across postnatal development. Cereb Cortex 2012, 22, 1215-1223. [CrossRef]

42. Ding, S.; Chen, B.; Zheng, Y.; Lu, Q.; Liu, L.; Zhuge, Q.C. Association study of OPRM1 polymorphisms with Schizophrenia in Han Chinese population. BMC Psychiat. 2013, 13, 107. [CrossRef] [PubMed]

43. Šerý, O.; Přikryl, R.; Častulík, L.; Št'astný, F. A118G polymorphism of OPRM1 gene is associated with schizophrenia. J. Mol. Neurosci. 2010, 41, 219-222. [CrossRef]

44. Scarr, E.; Money, T.T.; Pavey, G.; Neo, J.; Dean, B. Mu opioid receptor availability in people with psychiatric disorders who died by suicide: A case control study. BMC Psychiat. 2012, 12, 126. [CrossRef] 
45. Maes, M.; Chiavetto, L.B.; Bignotti, S.; Tura, G.-J.B.; Pioli, R.; Boin, F.; Kenis, G.; Bosmans, E.; De Jongh, R.; Altamura, C.A. Increased serum interleukin-8 and interleukin-10 in schizophrenic patients resistant to treatment with neuroleptics and the stimulatory effects of clozapine on serum leukemia inhibitory factor receptor. Schizophr. Res. 2002, 54, 281-291. [CrossRef]

46. Jimenez, N.; Puig, M.M.; Pol, O. Antiexudative effects of opioids and expression of $\kappa$-and $\delta$-opioid receptors during intestinal inflammation in mice: Involvement of nitric oxide. J. Pharmacol. Exp. Ther. 2006, 316, 261-270. [CrossRef] [PubMed]

47. Hipólito, L.; Wilson-Poe, A.; Campos-Jurado, Y.; Zhong, E.; Gonzalez-Romero, J.; Virag, L.; Whittington, R.; Comer, S.D.; Carlton, S.M.; Walker, B.M. Inflammatory pain promotes increased opioid self-administration: Role of dysregulated ventral tegmental area $\mu$ opioid receptors. J. Neurosci. 2015, 35, 12217-12231. [CrossRef]

48. Przewlocki, R.; Hassan, A.; Lason, W.; Epplen, C.; Herz, A.; Stein, C. Gene expression and localization of opioid peptides in immune cells of inflamed tissue: Functional role in antinociception. Neuroscience 1992, 48, 491-500. [CrossRef]

49. Panerai, A.E.; Sacerdote, P. $\beta$-endorphin in the immune system: A role at last? Immunol. Today 1997, 18, 317-319. [CrossRef]

50. Menzebach, A.; Hirsch, J.; Hempelmann, G.; Welters, I. Effects of endogenous and synthetic opioid peptides on neutrophil function in vitro. Br. J. Anaesth. 2003, 91, 546-550. [CrossRef]

51. Bidlack, J.M. Detection and function of opioid receptors on cells from the immune system. Clin. Diagnos Lab. Immunol. 2000, 7, 719-723. [CrossRef]

52. Suzuki, S.; Chuang, T.K.; Chuang, L.F.; Doi, R.H.; Chuang, R.Y. Morphine upregulates kappa-opioid receptors of human lymphocytes. Adv. Exp. Med. Biol. 2001, 493, 81-87. [PubMed]

53. Machelska, H.; Celik, M.Ö. Opioid Receptors in Immune and Glial Cells-Implications for Pain Control. Front. Immunol. 2020, 11, 300. [CrossRef] [PubMed]

54. Maher, D.P.; Walia, D.; Heller, N.M. Morphine decreases the function of primary human natural killer cells by both TLR4 and opioid receptor signaling. Brain Behav. Immun. 2020, 83, 298-302. [CrossRef] [PubMed]

55. Sharp, B.M. Multiple opioid receptors on immune cells modulate intracellular signaling. Brain Behav. Immun. 2006, 20, 9-14. [CrossRef]

56. Suzuki, S.; Miyagi, T.; Chuang, T.K.; Chuang, L.F.; Doi, R.H.; Chuang, R.Y. Morphine upregulates mu opioid receptors of human and monkey lymphocytes. Biochem. Biophys Res. Commun. 2000, 279, 621-628. [CrossRef]

57. Kraus, J. Regulation of mu-opioid receptors by cytokines. Front. Biosci 2009, 1, 164. [CrossRef]

58. Maes, M.; Kanchanatawan, B.; Sirivichayakul, S.; Carvalho, A.F. In schizophrenia, increased plasma IgM/IgA responses to gut commensal bacteria are associated with negative symptoms, neurocognitive impairments, and the deficit phenotype. Neurotox. Res. 2019, 35, 684-698. [CrossRef]

59. Langsdorf, E.F.; Mao, X.; Chang, S.L. A role for reactive oxygen species in endotoxin-induced elevation of MOR expression in the nervous and immune systems. J. Neuroimmunol. 2011, 236, 57-64. [CrossRef]

60. Basso, L.; Garnier, L.; Bessac, A.; Boué, J.; Blanpied, C.; Cenac, N.; Laffont, S.; Dietrich, G. T-lymphocyte-derived enkephalins reduce T h 1/T h 17 colitis and associated pain in mice. J. Gastroenterol. 2018, 53, 215-226. [CrossRef]

61. Laumet, G.; Ma, J.; Robison, A.J.; Susmita, K.; Heijnen, C.; Kavelaars, A. T cells as an emerging target for chronic pain therapy. Front. Mol. Neurosci. 2019, 12, 216. [CrossRef]

62. Mousa, S.A.; Machelska, H.; Schäfer, M.; Stein, C. Immunohistochemical localization of endomorphin-1 and endomorphin-2 in immune cells and spinal cord in a model of inflammatory pain. J. Neuroimmunol. 2002, 126, 5-15. [CrossRef]

63. Ninković, J.; Roy, S. Role of the mu-opioid receptor in opioid modulation of immune function. Amino Acids 2013, 45, 9-24. [CrossRef] [PubMed]

64. Chesnokova, E.; Dubynin, V.; Sarucheva, N.; Kalikhevich, V.; Ardemasova, Z.; Kamensky, A. Opioid peptides endomorphin-2 and soymorphin-5-amide are able to cross blood-brain barrier after intraperitoneal administration. J. Neurochem. 2013, 125, 229.

65. Ting, P.; Cushenberry, P.; Friedman, T.; Loh, Y. Enhanced Brain Opioid Receptor Activity Precedes Blood-Brain Barrier Disruption. In Brain Edema X; Springer: Vienna, Austria, 1997; pp. 250-253.

66. Maes, M.; Sirivichayakul, S.; Kanchanatawan, B.; Vodjani, A. Breakdown of the paracellular tight and adherens junctions in the gut and blood brain barrier and damage to the vascular barrier in patients with deficit schizophrenia. Neurotox. Res. 2019, 36, 306-322. [CrossRef] [PubMed] 
67. Liang, X.; Liu, R.; Chen, C.; Ji, F.; Li, T. Opioid system modulates the immune function: A review. Transl. Perioper. Pain Med. 2016, 1, 5-13. [PubMed]

68. Al-Fadhel, S.Z.; Al-Hakeim, H.K.; Al-Dujaili, A.H.; Maes, M. IL-10 is associated with increased mu-opioid receptor levels in major depressive disorder. Eur. Psychiat. 2019, 57, 46-51. [CrossRef]

69. Grimm, M.; Ben-Baruch, A.; Taub, D.; Howard, O.; Wang, J.; Oppenheim, J. Opiate inhibition of chemokine-induced chemotaxis. Ann. N. Y. Acad. Sci. 1998, 840, 9-20. [CrossRef]

70. Martin, J.L.; Koodie, L.; Krishnan, A.G.; Charboneau, R.; Barke, R.A.; Roy, S. Chronic morphine administration delays wound healing by inhibiting immune cell recruitment to the wound site. Am. J. Pathol. 2010, 176, 786-799. [CrossRef]

71. Long, X.; Li, Y.; Qiu, S.; Liu, J.; He, L.; Peng, Y. MiR-582-5p/miR-590-5p targeted CREB1/CREB5-NF-kB signaling and caused opioid-induced immunosuppression in human monocytes. Transl. Psychiatry 2016, 6, e757. [CrossRef]

72. Azuma, Y.; Ohura, K. Immunomodulation by Endomorphins 1 and 2 in Neutrophils, Macrophages and Microglia. Antiinflamm. Antiallergy Agents Med. Chem. 2003, 2, 1-8. [CrossRef]

73. Yang, X.; Xia, H.; Chen, Y.; Liu, X.; Zhou, C.; Gao, Q.; Li, Z. Inducible expression of endomorphins in murine dendritic cells. Neural Regen. Res. 2012, 7, 2811-2817. [PubMed]

74. Azuma, Y.; Ohura, K.; Wang, P.-L.; Shinohara, M. Endomorphins delay constitutive apoptosis and alter the innate host defense functions of neutrophils. Immunol. Lett. 2002, 81, 31-40. [CrossRef]

75. Jessop, D.S. Endomorphins as agents for the treatment of chronic inflammatory disease. Bio. Drugs 2006, 20, 161-166. [CrossRef] [PubMed]

76. Straub, R.H.; Wolff, C.; Fassold, A.; Hofbauer, R.; Chover-Gonzalez, A.; Richards, L.J.; Jessop, D.S. Antiinflammatory role of endomorphins in osteoarthritis, rheumatoid arthritis, and adjuvant-induced polyarthritis. Arthritis Rheum 2008, 58, 456-466. [CrossRef] [PubMed]

77. Maes, M.; Anderson, G.; Kubera, M.; Berk, M. Targeting classical IL-6 signalling or IL-6 trans-signalling in depression? Expert Opin. Ther. Tar. 2014, 18, 495-512. [CrossRef] [PubMed]

78. Borovcanin, M.M.; Jovanovic, I.; Radosavljevic, G.; Pantic, J.; Janicijevic, S.M.; Arsenijevic, N.; Lukic, M.L. Interleukin-6 in Schizophrenia-Is There a Therapeutic Relevance? Front. Psychiat. 2017, 8, 221. [CrossRef]

79. Fineberg, A.M.; Ellman, L.M. Inflammatory cytokines and neurological and neurocognitive alterations in the course of schizophrenia. Biol. Psychiat. 2013, 73, 951-966. [CrossRef]

80. Clark, S.D.; Abi-Dargham, A. The role of dynorphin and the kappa opioid receptor in the symptomatology of schizophrenia: A review of the evidence. Biol. Psychiat. 2019, 86, 502-511. [CrossRef]

81. Land, B.B.; Bruchas, M.R.; Lemos, J.C.; Xu, M.; Melief, E.J.; Chavkin, C. The dysphoric component of stress is encoded by activation of the dynorphin K-opioid system. J. Neurosci. 2008, 28, 407-414. [CrossRef]

82. Nemeth, C.L.; Paine, T.A.; Rittiner, J.E.; Béguin, C.; Carroll, F.I.; Roth, B.L.; Cohen, B.M.; Carlezon, W.A. Role of kappa-opioid receptors in the effects of salvinorin A and ketamine on attention in rats. Psychopharmacology 2010, 210, 263-274. [CrossRef]

83. Shekhar, A. Role of Kappa Opioid Receptors in Symptoms of Schizophrenia: What Is the Neurobiology? Biol. Psychiat. 2019, 86, 494-496. [CrossRef]

84. Yoshikawa, S.; Hareyama, N.; Ikeda, K.; Kurokawa, T.; Nakajima, M.; Nakao, K.; Mochizuki, H.; Ichinose, H. Effects of TRK-820, a selective kappa opioid receptor agonist, on rat schizophrenia models. Eur. J. Pharmacol. 2009, 606, 102-108. [CrossRef] [PubMed]

85. Escobar, A.P.; González, M.P.; Meza, R.C.; Noches, V.; Henny, P.; Gysling, K.; España, R.A.; Fuentealba, J.A.; Andrés, M.E. Mechanisms of kappa opioid receptor potentiation of dopamine D2 receptor function in quinpirole-induced locomotor sensitization in rats. Int. J. Neuropsychopharmacol. 2017, 20, 660-669. [CrossRef] [PubMed]

86. Heinke, B.; Gingl, E.; Sandkühler, J. Multiple targets of $\mu$-opioid receptor-mediated presynaptic inhibition at primary afferent A $\delta$-and C-fibers. J. Neurosci. 2011, 31, 1313-1322. [CrossRef] [PubMed]

87. Chen, Y.-B.; Huang, F.-S.; Fen, B.; Yin, J.-B.; Wang, W.; Li, Y.-Q. Inhibitory effects of endomorphin-2 on excitatory synaptic transmission and the neuronal excitability of sacral parasympathetic preganglionic neurons in young rats. Front. Cell Neurosci. 2015, 9, 206. [CrossRef]

88. Gelman, P.L.; Herrera, N.E.G.; Ortega, M.E.M.; Villanueva, E.B.; Santillán, C.T.; Juárez, A.S.; Palma, B.A. Endomorphin peptides: Pharmacological and functional implications of these opioid peptides in the brain of mammals. Part two. Salud Ment. 2010, 33, 257-272. 
89. Sakurada, S.; Sawai, T.; Mizoguchi, H.; Watanabe, H.; Watanabe, C.; Yonezawa, A.; Morimoto, M.; Sato, T.; Komatsu, T.; Sakurada, T. Possible involvement of dynorphin A release via $\mu 1$-opioid receptor on supraspinal antinociception of endomorphin-2. Peptides 2008, 29, 1554-1560. [CrossRef]

90. Willis, W.D., Jr.; Coggeshall, R.E. Chemical Anatomy of Dorsal Root Ganglion Cell. In Sensory Mechanisms of the Spinal Cord: Volume 1 Primary Afferent Neurons and the Spinal Dorsal Horn; Springer Science \& Business Media: Berlin/Heidelberg, Germany, 2012; Chapter 4; pp. 103-154.

91. Gein, S.V. Dynorphins in regulation of immune system functions. Biochem (Mosc) 2014, 79, 397-405. [CrossRef]

92. Offermanns, S.; Rosenthal, W. Encyclopedia of molecular pharmacology; Springer Science \& Business Media: Berlin, Germany, 2008; pp. 904-908.

93. Terskiy, A.; Wannemacher, K.M.; Yadav, P.N.; Tsai, M.; Tian, B.; Howells, R.D. Search of the human proteome for endomorphin-1 and endomorphin-2 precursor proteins. Life Sci. 2007, 81, 1593-1601. [CrossRef]

94. Kou, Z.-Z.; Wan, F.-P.; Bai, Y.; Li, C.-Y.; Hu, J.-C.; Zhang, G.-T.; Zhang, T.; Chen, T.; Wang, Y.-Y.; Li, H. Decreased endomorphin-2 and $\mu$-opioid receptor in the spinal cord are associated with painful diabetic neuropathy. Front. Mol. Neurosci. 2016, 9, 80. [CrossRef]

(C) 2020 by the authors. Licensee MDPI, Basel, Switzerland. This article is an open access article distributed under the terms and conditions of the Creative Commons Attribution (CC BY) license (http://creativecommons.org/licenses/by/4.0/). 